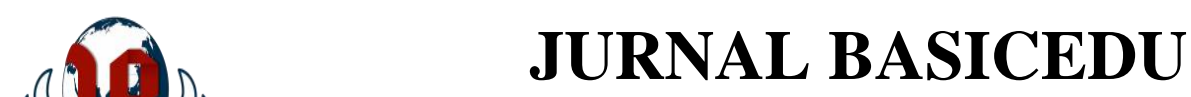

Volume 5 Nomor 4 Tahun 2021 Halaman 2384 - 2394

Research \& Learning in Elementary Education

https://jbasic.org/index.php/basicedu

P AHLAWAN

\title{
Pengembangan Media Video Animasi Berbasis Aplikasi Canva untuk Meningkatkan Motivasi dan Prestasi Belajar Siswa
}

\author{
Gita Permata Puspita Hapsari ${ }^{1}$, Zulherman $^{2 凶}$ \\ Universitas Muhammadiyah Prof. Dr. Hamka, Indonesia ${ }^{1,2}$ \\ E-mail: gitapph@gmail.com ${ }^{1}$, zulherman@uhamka.ac.id ${ }^{2}$
}

\begin{abstract}
Abstrak
Dimasa pandemi Covid-19 ini, berbagai kebijakan dilakukan untuk memutus rantai penyebaran termasuk pada bidang pendidikan. Tujuan dari penelitian ini yaitu untuk mengetahui efektivitas dan kelayakan media video animasi berbasis aplikasi Canva pada materi gaya dan gerak. Penelitian ini menggunakan penelitian Research and Development (R\&D) dan model yang digunakan adalah model Pengembangan ADDIE. Produk ini divalidasi oleh 1 ahli media, 1 ahli materi, 3 guru dan 29 siswa kelas 4 . Pada tahap awal dilakukan uji validasi oleh ahli media, ahli materi, dan guru. Kemudian menguji efektifitas media berupa pretest-posttest dan uji validasi oleh siswa. Hasil validasi menunjukkan ahli media memperoleh rata-rata $65,45 \%$ yang termasuk kedalam kriteria "Valid", untuk hasil validasi ahli materi dan guru memperoleh kategori "Sangat Valid" dengan hasil masing-masing $86 \%$ dan 85,57\%, dan uji validasi siswa diperoleh hasil sebesar $90 \%$ yang termasuk dalam kriteria "Sangat Baik". Hasil tes menunjukkan bahwa secara keseluruhan rata-rata peningkatan hasil belajar yang diperoleh siswa yaitu $0,56 \%$, dengan kategori "Sedang”. Dapat disimpulkan bahwa produk video animasi berbasis aplikasi Canva ini dapat meningkatkan motivasi dan prestasi belajar siswa serta layak digunakan dalam proses pembelajaran.
\end{abstract}

Kata Kunci: media video animasi, Canva, gaya dan gerak.

\begin{abstract}
During the Covid-19 pandemic, various policies were carried out to break the chain of spread, including in the education sector. The purpose of this study was to determine the effectiveness and feasibility of Canva application-based animated video media on force and motion material. This study uses Research and Development $(R \& D)$ research and ADDIE Development model. This product was validated by 1 media expert, 1 material expert, 3 teachers, and 29 grade 4 students. At the initial stage, validation tests were carried out by media experts, material experts, and teachers. Then test the effectiveness of the media in the form of pretestposttest and validation tests by students. The validation results show that media experts get an average of $65.45 \%$ in the "Valid" criteria, for the validation results material experts and teachers get the "Very Valid" criteria with the results of $86 \%$ and $85.57 \%$ respectively, for students, the average result is $90 \%$ included in the "Very Good" criteria. The test results show that the average increase in learning outcomes is $0.56 \%$ which is included in the "Medium" category. It can be concluded that this Canva application-based animated video product can increase student motivation and achievement and is suitable for the learning process.
\end{abstract}

Keywords: animated video media, Canva, force and motion.

Copyright (c) 2021 Gita Permata Puspita Hapsari, Zulherman

$\triangle$ Corresponding author :

Email : zulherman@uhamka.ac.id

DOI $\quad:$ https://doi.org/10.31004/basicedu.v5i4.1237

ISSN 2580-3735 (Media Cetak)

ISSN 2580-1147 (Media Online)

Jurnal Basicedu Vol 5 No 4 Tahun 2021

p-ISSN 2580-3735 e-ISSN 2580-1147 
2385 Pengembangan Media Video Animasi Berbasis Aplikasi Canva untuk Meningkatkan Motivasi dan Prestasi Belajar Siswa - Gita Permata Puspita Hapsari, Zulherman

DOI: https://doi.org/10.31004/basicedu.v5i4.1237

\section{PENDAHULUAN}

Perkembangan Ilmu Pengetahuan dan Teknologi (IPTEK) sangat berpengaruh besar pada kehidupan sehari-hari. Mengutip Kemdikbud RI, perkembangan ilmu dan teknologi berpengaruh terhadap berbagai aspek kehidupan manusia karena memudahkan dalam berbagai aktivitas dan pekerjaan manusia (Putri, 2020). Maka dari itu kita harus mampu beradaptasi pada perubahan yang terjadi.

Dimasa pandemi Covid-19 ini, perubahan terjadi dalam berbagai aspek terutama pada aspek pendidikan. Covid-19 merupakan virus yang menyebabkan gangguan pada sistem pernapasan. Saat ini virus tersebut sudah menyebar cepat hampir ke seluruh penjuru dunia. Berdasarkan data yang diperoleh dari WHO, pada 23 Juli 2021 tercatat sebanyak 192.284.207 kasus COVID-19 yang terkonfirmasi positif termasuk 4.136.518 kematian di seluruh dunia. Di Indonesia sendiri terkonfirmasi sebanyak 3.082.410 positif Covid-19 dan 80.598 kematian (WHO, 2021). Berbagai kebijakan dilakukan untuk memutus rantai penyebaran virus terutama pada bidang pendidikan.

Pembelajaran Jarak Jauh menjadi solusi untuk meminimalisir penyebaran Covid-19. Pada tanggal 24 maret 2020 Menteri Pendidikan dan Kebudayaan Republik Indonesia mengeluarkan Surat Edaran Nomor 4 Tahun 2020 Tentang Pelaksanaan Kebijakan Pendidikan Dalam Masa Darurat Penyebaran COVID, dalam Surat Edaran tersebut dijelaskan bahwa proses belajar dilaksanakan di rumah melalui pembelajaran daring/jarak jauh dilaksanakan untuk memberikan pengalaman belajar yang bermakna bagi siswa (Astini, 2020). Pembelajaran ini memanfaatkan platform untuk mendukung proses pembelajaran secara daring. Ruang diskusi yang sering digunakan oleh guru dan siswa yaitu Whatsapp, Google Classrom, Zoom, Google Meet, dan sebagainya.

Dalam suatu pembelajaran yang menarik dan inovatif diperlukan media pembelajaran untuk membantu guru dalam mengajar. Media pembelajaran merupakan segala sesuatu yang dapat digunakan untuk menyalurkan pesan pengirim kepada penerima, sehingga dapat merangsang pikiran, perasaan perhatian, dan minat peserta didik untuk belajar (Tafonao, 2018). Media pembelajaran sangat diperlukan untuk meningkatkan, membangkitkan keinginan dan minat baru dalam proses pembelajaran (Zulherman et al., 2021). Namun dalam prakteknya, masih banyak dijumpai guru-guru yang yang belum menerapkan media pembelajaran secara inovatif, bukan hanya tidak menerapkan media tersebut, namun sama sekali tidak ada media pembelajaran disekolah (Tafonao, 2018).

Teknologi Informasi dan Komunikasi dapat dimanfaatkan untuk membuat suatu media pembelajaran yang menarik dan menyenangkan. Mengingat saat ini pembelajaran dilakukan secara daring, guru harus mampu mengembangkan media pembelajaran dengan memanfaatkan TIK. Selain mampu menggunakan TIK sebagai sumber belajar guru juga dituntut untuk mampu menciptakan pembelajaran yang kreatif dan inovatif yang terintegrasi dengan TIK (Maryanti \& Kurniawan, 2017). Video animasi merupakan salah satu media pembelajaran yang cocok untuk menciptakan media pembelajaran yang menarik.

Video animasi merupakan gabungan dari media audio visual yang bergerak. Media audio visual mengandalkan indera pendengaran dan penglihatan. Anak sekolah dasar (SD) pada umumnya belajar 50\% dari apa yang didengar dan dilihat (Hikmah \& Purnamasari, 2017). Sehingga siswa lebih memahami suatu pembelajaran dari apa yang dilihat dan didengar. Ilmu Pengetahuan Alam merupakan salah pembelajaran yang sulit dipahami. Mata pelajaran IPA banyak memiliki konsep-konsep bersifat abstrak yang dapat menimbulkan miskonsepsi pada siswa. Materi IPA seharusnya lebih dikaitkan dalam kehidupan sehari-hari siswa dan budaya setempat sehingga siswa merasa pengetahuan yang didapatkannya dapat berguna dalam kehidupan nyata siswa (Dwipayana et al., 2020). Dengan adanya media video dalam pembelajaran, guru terbantu ketika menyampaikan materi dan suasana belajar tidak monoton, serta akan membantu siswa dalam memahami materi dengan mudah (Kurniawan et al., 2018). Jadi jika materi IPA tersebut dikemas menjadi sebuah video animasi maka dapat membuat siswa tertarik dan termotivasi dalam belajar. Materi gaya dan gerak pada tematik kelas IV merupakan materi yang kami pilih untuk mengembangkan media video animasi berbasis aplikasi Canva. 
2386 Pengembangan Media Video Animasi Berbasis Aplikasi Canva untuk Meningkatkan Motivasi dan Prestasi Belajar Siswa - Gita Permata Puspita Hapsari, Zulherman

DOI: https://doi.org/10.31004/basicedu.v5i4.1237

Berdasarkan hasil angket analisis kebutuhan dengan 10 guru kelas IV dan 163 siswa kelas IV sekolah dasar yang berada di Jakarta dan Wonogiri, didapatkan fakta bahwa metode yang paling banyak sering digunakan dalam pembelajaran IPA secara daring yaitu penugasan, media berbasis teknologi yang didapatkan guru paling banyak diperoleh dari internet, kebanyakan siswa mengalami kesulitan dalam memahami pembelajaran IPA, serta hasil dari analisis kebutuhan 90\% guru menyatakan bahwa media video animasi berbasis Canva itu menarik, 90\% guru menyatakan perlu dan setuju menggunakan media video animasi berbasis aplikasi Canva dalam pembelajaran IPA. Hasil analisis pada siswa menunjukkan tidak jauh dari hasil analisis pada guru yaitu 91,4\% siswa menyatakan bahwa media video animasi berbasis aplikasi Canva itu menarik dan $83,4 \%$ siswa menyatakan perlu menggunakan media video aplikasi Canva dalam pembelajaran IPA. Hal ini perlu dilakukan karena bisa menambah kemenarikan penyajian materi pelajaran, serta menambah motivasi siswa untuk belajar, apalagi pembelajaran dilakukan secara daring (Rahmatullah et al., 2020).

Jadi, Guru dan siswa menyatakan bahwa media video animasi berbasis aplikasi Canva sangat menarik dan perlu menggunakan media pembelajaran media berbasis aplikasi Canva untuk menjelaskan materi IPA. Berdasarkan hasil analisis kebutuhan tersebut, mengindikasi bahwa upaya untuk meningkatkan kualitas pendidikan kurang maksimal, terutama pada penggunaan media pembelajaran. Penggunaan media belum cukup maksimal dalam mendukung proses pembelajaran. Hal tersebut dikarenakan kebanyakan media yang beredar di internet kurang mengaitkan materi ke dalam kehidupan sehari-hari sehingga siswa merasa pembelajaran yang diperoleh tidak bermanfaat bagi kehidupannya (Dwipayana et al., 2020). Pembelajaran IPA memiliki konsep yang terkait dengan kehidupan sehari-hari dan memiliki konsep abstrak. Kehadiran media dalam kegiatan pembelajaran akan mengubah materi yang abstrak menjadi sesuatu yang konkrit. Siswa lebih termotivasi jika pelajaran yang diberikan membawa siswa ke dunia nyata dan konkrit sesuai dengan perkembangan kematangan siswa usia sekolah dasar (Ananda, 2017). Hal-hal tersebutlah yang diduga menyebabkan siswa mengalami kesulitan dalam memahami pembelajaran IPA dan tertarik dengan media video animasi berbasis aplikasi canva dalam menyampaikan materi IPA. Permasalahan tersebut dapat diatasi dengan adanya media video animasi berbasis Aplikasi Canva.

Aplikasi Canva merupakan aplikasi desain grafis secara online. Canva juga memiliki berbagai macam template atau opsi desain yang ingin dibuat. Tidak hanya presentasi. Tapi Canva juga menyediakan desain untuk poster, foto profil, banner, dan lain-lain (Leryan et al., 2018). Penggunaan media pembelajaran canva dapat mempermudah dan menghemat waktu guru dalam mendesain media pembelajaran serta mempermudah guru dalam menjelaskan materi pembelajaran. Media canva juga dapat memudahkan peserta didik dalam memahami pelajaran dikarenakan media ini dapat menampilkan teks, video, animasi, audio, gambar, grafik dan lain-lain sesuai dengan tampilan yang diinginkan dan dapat membuat peserta didik untuk fokus memperhatikan pelajaran karena tampilannya yang menarik (Tanjung \& Faiza, 2019). Aplikasi Canva ini diharapkan menjadi alternatif guru dalam membuat suatu media video animasi yang menarik pada materi "Gaya dan Gerak".

Berdasarkan latar belakang masalah yang telah dikemukakan diatas, bahwa kami tertarik untuk meneliti permasalahan tersebut dengan judul "Pengembangan Media Video Animasi berbasis Aplikasi Canva pada Materi Gaya dan Gerak untuk Meningkatkan Motivasi dan Prestasi Belajar Siswa". Tujuan dari penelitian ini yaitu mengembangkan media video animasi untuk mengetahui efektivitas dan kelayakan produk. Berdasarkan latar belakang diatas, maka rumusan rmasalah penelitan ini yaitu (1) Bagaimana pengembangan media video animasi berbasis aplikasi Canva pada materi gaya dan gerak untuk meningkatkan motivasi dan prestasi belajar siswa? (2) Bagaimana hasil pengembangan media video animasi berbasis aplikasi Canva sehingga layak digunakan dalam pembelajaran IPA?

\section{METODE}

Penelitian ini menggunakan penelitian Research and Development (R\&D) dan model yang digunakan adalah model Pengembangan ADDIE yang terdiri dari lima tahapan yaitu (1) Analysis (2) Design (3) 
2387 Pengembangan Media Video Animasi Berbasis Aplikasi Canva untuk Meningkatkan Motivasi dan Prestasi Belajar Siswa - Gita Permata Puspita Hapsari, Zulherman

DOI: https://doi.org/10.31004/basicedu.v5i4.1237

Development (4) Implementation and (5) Evaluation (Dadi et al., 2019). Penelitian ini dilaksanakan pada semester 1 pada bulan Juli sampai dengan bulan Agustus. Subjek penelitian ini adalah siswa kelas IV SDN 3 Tubokarto, SDN 2 Trukan, dan SDN 3 Watangrejo, dengan total siswa sebanyak 29 orang.

Metode penelitian yang digunakan yaitu metode survei. Metode survei ini menggunakan teknik pengumpulan data dengan menggunakan kuisioner/angket, tes, dan dokumentasi. Metode angket digunakan untuk mengetahui suatu produk dengan menguji validasi produk yang kami kembangkan. Untuk menjaga kualitas instrumen, makan perlu diperoleh opini dari ahli atau dengan kata lain perlu validasi(Hikmah \& Purnamasari, 2017). Instrumen yang digunakan yaitu angket validasi ahli materi, ahli media, pengguna (Guru), dan respon siswa. Untuk mengevaluasi media pembelajaran diperlukan 1 ahli media, 1 ahli materi, 3 guru kelas, dan 29 siswa dari 3 sekolah. Data validasi ini kumpulkan melalui penyebaran angket berupa google form yang diisi melalui link scara online dengan skala likert. Berikut skala penilaian validasi produk mengguakan skala likert.

Tabel 1

Skala Penilaian Validasi Produk

\begin{tabular}{cc}
\hline Skor & Kriteria \\
\hline 5 & Sangat Baik \\
\hline 4 & Baik \\
\hline 3 & Sedang \\
\hline 2 & Buruk \\
\hline 1 & Buruk Sekali \\
\hline \multicolumn{2}{l}{ (Oktaviara \& Pahlevi, 2019) }
\end{tabular}

Metode tes yang digunakan yaitu tes hasil belajar pretest-postest berupa tes objektif atau pilihan ganda. Tes objektif atau pilihan ganda ini digunakan pada uji efektifitas produk hasil belajar siswa (Ponza et al., 2018). Tes hasil belajar dilakukan dua kali yaitu sebelum dan sesudah dilakukan uji coba produk pengembangan. Tes ini berguna untuk mengetahui pengaruhnya terhadap motivasi dan prestasi belajar siswa. Instrumen yang digunakan yaitu soal pretest-postest dengan menggunakan google form. Data hasil pretest-pottest dianalisis menggunakan uji N-Gain score untuk mengetahui meningkatnya prestasi belajar siswa.

Teknik analisis yang digunakan dalam penelitian ini yaitu sebagai berikut :

Analisis data hasil validasi dari ahli materi, ahli media, dan guru:

$$
P=\frac{f}{N} \times 100
$$

Keterangan :

$\mathrm{P}=$ Persentase validitas

$\mathrm{F}=$ Jumlah skor hasil pengumpulan data

$\mathrm{N}=$ Skor maksimal

Tabel 2

Persentase Kriteria Validitas

\begin{tabular}{cc}
\hline Presentase & Kriteria \\
\hline $81 \%-100 \%$ & Sangat Valid \\
\hline $61 \%-80 \%$ & Valid \\
\hline $41 \%-60 \%$ & Kurang Valid \\
\hline $21 \%-40 \%$ & Tidak Valid \\
\hline $0 \%-20 \%$ & Sangat Tidak valid \\
\hline \multicolumn{2}{c}{ (Jannah \& Julianto, 2018) }
\end{tabular}


2388 Pengembangan Media Video Animasi Berbasis Aplikasi Canva untuk Meningkatkan Motivasi dan Prestasi Belajar Siswa - Gita Permata Puspita Hapsari, Zulherman

DOI: https://doi.org/10.31004/basicedu.v5i4.1237

Analisis Data Hasil Respon Siswa

$$
P=\frac{f}{N} \times 100
$$

Keterangan :

$\mathrm{P}=$ Persentase validitas

$\mathrm{F}=$ Jumlah skor hasil pengumpulan data

$\mathrm{N}=$ Skor maksimal

Tabel 3

Persentasi Hasil Respon Siswa

\begin{tabular}{cc}
\hline Presentase & Kriteria \\
\hline $81 \%-100 \%$ & Sangat Baik \\
\hline $61 \%-80 \%$ & Baik \\
\hline $41 \%-60 \%$ & Cukup Baik \\
\hline $21 \%-40 \%$ & Kurang Baik \\
\hline $0 \%-20 \%$ & Sangat Tidak Baik \\
\hline \multicolumn{2}{c}{$($ Jannah \& Julianto, 2018) }
\end{tabular}

Analisis Data Hasil Tes Siswa

Analisis data hasil belajar dilakukan dengan membandingkan hasil nilai dari pretest dan posttest. Adapun rumus N-Gain yang digunakan :

$$
\begin{gathered}
N-\text { Gain }=\frac{\text { Skor Postest }- \text { SkorPretest }}{\text { Skor Maksimal }- \text { Skor Pretest }} \\
\text { Tabel } 4 \\
\text { Persentasi Hasil Respon Siswa }
\end{gathered}
$$

\begin{tabular}{cc}
\hline Presentase & Kriteria \\
\hline$-1,00<\mathrm{g}<0,00$ & Menurun \\
\hline $\mathrm{g}=0,00$ & Stabil \\
\hline $0,00<\mathrm{g}<0,03$ & Rendah \\
\hline $0,03<\mathrm{g}<0,70$ & Sedang \\
\hline $0,07<\mathrm{g}<1,00$ & Tinggi \\
\hline \multicolumn{2}{c}{ (Maulana Arifin et al., 2020) }
\end{tabular}

\section{HASIL DAN PEMBAHASAN}

Hasil penelitian yang berjudul "Pengembangan Media Video Animasi Berbasis Aplikasi Canva pada Materi Gaya dan Gerak untuk Meningkatkan Motivasi dan Prestasi belajar Siswa" telah dilaksanakan dengan tahapan model Pengembangan ADDIE pada penelitian Research and Development (R\&D). Media video animasi berbasis aplikasi Canva merupakan produk yang dihasilkan dari penelitian ini.

\section{Hasil Kelayakan Media Video Animasi Berbasis Aplikasi Canva}

Hasil Kevalidan Media Video Animasi Berbasis Aplikasi Canva

Kami melaksanakan validasi uji kelayakan kepada ahli media dan ahli materi. Validasi media merupakan proses untuk menilai rancangan produk oleh para ahli yang berpengalaman (Dewanti et al., 2018). Hal ini bertujuan untuk mengetahui kelayakan dari media pembelajaran dan mengetahui kelemahan dari media tersebut. Validasi dilakukan dengan pemberian penilaian produk berdasarkan acuan/aspek/indikator yang terdapat pada 
instrumen validasi oleh validator ahli (Silmi \& Rachmadyanti, 2018). Berikut pemaparan analisis data dan tanggapan dari para ahli terhadap media tersebut.

a. Validasi Ahli Media

Validasi ahli media adalah Bapak Ardian Arifin, S. Kom, M.Pd. Berikut ini hasil uji validasi ahli media dan ahli materi pada media video animasi berbasis aplikasi Canva.

Tabel 5

Hasil Validasi Ahli Media

\begin{tabular}{|c|c|c|c|c|}
\hline \multicolumn{5}{|c|}{ (a) } \\
\hline Aspek & Indikator & No. Butir & $\begin{array}{l}\text { Rata-Rata } \\
\text { Presentase }\end{array}$ & Kriteria \\
\hline \multirow{6}{*}{ Visual } & $\begin{array}{l}\text { Kesesuaian tampilan dengan } \\
\text { background. }\end{array}$ & 1 & \multirow{6}{*}{$53,33 \%$} & \multirow{6}{*}{ Kurang Valid } \\
\hline & Kombinasi warna yang menarik. & 2 & & \\
\hline & $\begin{array}{l}\text { Kesesuaian setting gambar dan } \\
\text { animasi }\end{array}$ & 6 & & \\
\hline & $\begin{array}{l}\text { Kesesuaian penyajian gambar dengan } \\
\text { materi yang dibahas }\end{array}$ & 7 & & \\
\hline & $\begin{array}{l}\text { Animasi tulisan yang ditampilkan jelas } \\
\text { dan menarik }\end{array}$ & 8 & & \\
\hline & $\begin{array}{l}\text { Ilustrasi mudah dipahami dan sesuai } \\
\text { dengan kehidupan sehari-hari }\end{array}$ & 9 & & \\
\hline \multirow{3}{*}{ Audio } & $\begin{array}{l}\text { Kesesuaian musik pengiring dengan } \\
\text { narasi }\end{array}$ & 3 & \multirow{3}{*}{$86,67 \%$} & \multirow{3}{*}{ Sangat Valid } \\
\hline & Suara yang disajikan jelas & 4 & & \\
\hline & Antara suara dengan animasi sesuai & 5 & & \\
\hline Kualitas & Kualitas video bagus & 10 & $60 \%$ & Kurang Valid \\
\hline Isi & Isi video runtut sesuai materi & 11 & $80 \%$ & Valid \\
\hline & Rata-Rata & & $65,45 \%$ & Valid \\
\hline
\end{tabular}

Berdasarkan hasil rata-rata persentase validasi secara keseluruhan diatas menunjukkan kriteria "Valid" dengan rata-rata $65,45 \%$. Adapun komentar dan saran dari ahli media yaitu perbaiki isi materi dan animasinya. Perbaikan atau revisi dilakukan setelah didapatkannya saran yang diberikan oleh validator materi dan validator media mengenai beberapa komponen (Silmi \& Rachmadyanti, 2018).

b. Validasi Ahli Materi

Validasi Ahli Materi adalah Bapak Erwinsyah Satria, M.Si., M.Pd. Berikut ini hasil uji ahli materi pada media video animasi berbasis aplikasi Canva.

Tabel 6

Hasil Validasi Ahli Materi

\begin{tabular}{|c|c|c|c|c|}
\hline Aspek & Indikator & No. Butir & $\begin{array}{l}\text { Rata-Rata } \\
\text { Presentase }\end{array}$ & Kriteria \\
\hline \multirow{4}{*}{$\begin{array}{l}\text { Kelayakan } \\
\text { Isi }\end{array}$} & Kesesuaian isi dengan KD dan Indikator & 6 & \multirow{4}{*}{$93,33 \%$} & \multirow{4}{*}{ Sangat Valid } \\
\hline & Penyajian materi yang sistematis & 2 & & \\
\hline & $\begin{array}{l}\text { Ilustrasi yang mendukung kejelasan } \\
\text { materi. }\end{array}$ & 5 & & \\
\hline & Penampilan video menarik & 4 & & \\
\hline \multirow{2}{*}{$\begin{array}{l}\text { Kelayakan } \\
\text { Penyajian }\end{array}$} & $\begin{array}{l}\text { Kemudahan memahami materi } \\
\text { menggunakan media video animasi }\end{array}$ & 1 & \multirow{2}{*}{$85 \%$} & \multirow{2}{*}{ Sangat Valid } \\
\hline & $\begin{array}{l}\text { Kesesuaian kombinasi warna, tulisan, } \\
\text { dan gambar }\end{array}$ & 3 & & \\
\hline
\end{tabular}


2390 Pengembangan Media Video Animasi Berbasis Aplikasi Canva untuk Meningkatkan Motivasi dan Prestasi Belajar Siswa - Gita Permata Puspita Hapsari, Zulherman

DOI: https://doi.org/10.31004/basicedu.v5i4.1237

\begin{tabular}{clccc}
\hline \multirow{2}{*}{ Aspek } & \multicolumn{1}{c}{ Indikator } & No. Butir & $\begin{array}{c}\text { Rata-Rata } \\
\text { Presentase }\end{array}$ & Kriteria \\
\hline & Kejelasan ilustrasi gambar & 7 & & \\
\cline { 1 - 3 } $\begin{array}{c}\text { Kelayakan } \\
\text { Bahasa }\end{array}$ & Struktur kalimat yang digunakan jelas & 9 & & \multirow{2}{*}{$80 \%$} \\
\cline { 2 - 3 } & Bahasa yang digunakan komunikatif & 10 & Valid \\
\cline { 2 - 3 } & $\begin{array}{l}\text { Bahasa yang digunakan sesuai dengan } \\
\text { EYD }\end{array}$ & 8 & & \\
\hline & Rata-Rata & & $86 \%$ & Sangat Valid \\
\hline
\end{tabular}

Berdasarkan hasil rata-rata presentase validasi ahli materi yaitu 86\%, menunjukkan bahwa materi dalam media video animasi berbasis aplikasi Canva tersebut termasuk ke dalam kriteria "Sangat Valid". Komentar dan saran dari ahli materi yaitu gunakan animasi yang bergerak untuk jenis gaya listrik dan magnet agar biar lebih jelas dan konkret bagi anak, lalu pada manfaat gaya listrik dan gravitasi harus dibuat demontrasi animasi yang bergerak biar lebih jelas agar dapat dipahami oleh siswa.

Hasil Uji Coba Produk

Uji coba media video animasi berbasis aplikasi Canva ini dilakukan kepada guru sebagai pengguna dan siswa kelas IV.

a. Uji Coba Pengguna (Guru)

Uji coba dilakukan oleh 3 guru kelas IV dari 3 sekolah dasar. Adapun nama-nama guru kelas tersebut yaitu Ibu Ika Puji Hastuti S.Pd, Ibu Riyanti S.E.,S.Pd, dan Bapak Dwi Samsidi, S.Pd. Berikut ini hasil angket respon siswa terhadap media video animasi berbasis aplikasi Canva. Berikut ini hasil uji coba pengguna (guru) terhadap media video animasi berbasis aplikasi Canva.

Tabel 7

Hasil Uji Coba Pengguna (Guru)

\begin{tabular}{|c|c|c|c|c|}
\hline Aspek & Indikator & No. Butir & $\begin{array}{l}\text { Rata-Rata } \\
\text { Presentase }\end{array}$ & Kriteria \\
\hline \multirow[t]{2}{*}{ Visual } & $\begin{array}{l}\text { Animasi (gambar-gambar yang bergerak } \\
\text { menarik). }\end{array}$ & 12 & \multirow[t]{2}{*}{$83,33 \%$} & \multirow[t]{2}{*}{ Sangat Valid } \\
\hline & Komposisi warna tepat. & 13 & & \\
\hline \multirow{2}{*}{ Audio } & Menggunakan efek suara. & 8 & \multirow{2}{*}{$86,67 \%$} & \multirow{2}{*}{ Sangat Valid } \\
\hline & Ada muatan musik dalam media. & 14 & & \\
\hline \multirow{8}{*}{ Isi } & $\begin{array}{l}\text { Relevan dengan tujuan kurikulum dan } \\
\text { sasaran belajar. }\end{array}$ & 1 & \multirow{8}{*}{$90,83 \%$} & \multirow{8}{*}{ Sangat Valid } \\
\hline & $\begin{array}{l}\text { Materi yang disajikan sesuai silabus mata } \\
\text { pelajaran IPA kelas IV. }\end{array}$ & 2 & & \\
\hline & $\begin{array}{l}\text { Materi sesuai dengan kompetensi dasar } \\
\text { dan standar kompetensi yang ingin dicapai. }\end{array}$ & 3 & & \\
\hline & $\begin{array}{l}\text { Materi yang disajikan sesuai dengan tujuan } \\
\text { pembelajaran IPA Kelas IV. }\end{array}$ & 4 & & \\
\hline & Alur Pembelajaran jelas. & 5 & & \\
\hline & Kejelasan materi. & 6 & & \\
\hline & $\begin{array}{l}\text { Video animasi yang disajikan memperjelas } \\
\text { materi. }\end{array}$ & 10 & & \\
\hline & $\begin{array}{l}\text { Ada video yang mengandung } \\
\text { pembelajaran IPA dalam dunia nyata. }\end{array}$ & 11 & & \\
\hline \multirow{2}{*}{$\begin{array}{l}\text { Bahasa dan } \\
\text { Tulisan }\end{array}$} & Keterbacaan tulisan & 7 & \multirow{2}{*}{$86,67 \%$} & \multirow{2}{*}{ Sangat Valid } \\
\hline & Artikulasi bahasa jelas dan dapat dipahami & 9 & & \\
\hline
\end{tabular}




\begin{tabular}{|c|c|c|c|c|}
\hline Aspek & Indikator & No. Butir & $\begin{array}{l}\text { Rata-Rata } \\
\text { Presentase }\end{array}$ & Kriteria \\
\hline & Rata-Rata & & $85,57 \%$ & Sangat Valid \\
\hline
\end{tabular}

Berdasarkan hasil penilaian yang dilakukan oleh guru terhadap media pembelajaran ini, secara keseluruhan menunjukkan kategori "Sangat Valid" dengan nilai rata-rata sebanyak 85,57\%. Sehingga dikatakan bahwa media video animasi berbasis aplikasi Canva ini layak untuk digunakan.

b. Uji Coba Siswa

Uji coba ini dilakukan oleh 29 siswa dari 3 sekolah dasar. Setelah kami menyajikan media video animasi berbasis aplikasi Canva ini dan telah selesai melaksanakan pretest-postest, siswa diminta mengisi angket respon siswa terhadap media pembelejaran tersebut. Berikut hasil angket respon siswa terhadap media video animasi berbasis aplikasi Canva.

Tabel 8

Hasil Angket Respon Siswa

\begin{tabular}{clccc}
\hline \multirow{2}{*}{ Aspek } & \multicolumn{1}{c}{ Indikator } & No. Butir & $\begin{array}{c}\text { Rata-Rata } \\
\text { Presentase }\end{array}$ & Kriteria \\
\cline { 1 - 3 } Software & Kemenarikan media. & 1 dan 4 & \multirow{2}{*}{$89,48 \%$} & Sangat Baik \\
\cline { 2 - 3 } & Kemudahan pengguna. & 2 dan 3 & & \\
\hline Materi & Bahasa dan maksud materi. & 7 & $90,34 \%$ & Sangat Baik \\
\hline Komunikasi & Tampilan dan teks. & 8 & $91,03 \%$ & Sangat Baik \\
\hline Visual & Animasi dan video & 5 dan 6 & $90,69 \%$ & Sangat Baik \\
\hline & Rata-Rata & & $90,09 \%$ & Sangat Baik \\
\hline
\end{tabular}

Berdasarkan hasil rata-rata respon siswa diatas menunjukkan sebanyak 90\%, sehingga media pembelajaran tersebut diperoleh kategori "Sangat Baik". Hal ini membuktikan bahwa media video animasi berbais aplukasi Canva ini layak untuk digunakan pada proses pembelajaran. Artinya desain media pembelajaran tersebut disukai oleh siswa baik baik dari aspek kelengkapan konten maupun tampilannya, sehingga dapat digunakan di sekolah tempat uji coba (Rahmatullah et al., 2020).

Efektivitas Produk Media Video Animasi Berbasis Aplikasi Canva

Hasil belajar siswa dilakukan untuk mengetahui efektivitas media video animasi berbasis aplikasi canva. Apabila hasil belajar siswa mengalami peningkatan, maka media video animasi berbasis aplikasi canva ini dikatakan efektif. Setelah media divalidasi dan direvisi kemudian dilakukan uji coba pada guru, lalu dilanjutkan dengan uji coba kepada siswa untuk mengetahui efektifitas produk.

Uji coba ini dilakukan dengan memberikan pretest-posttest berupa soal pilihan ganda berjumlah 15 soal. Dalam uji coba ini terdapat 2 video yang berbeda yaitu yang pertama video penjelasan materi oleh kami secara verbal untuk pretest dan yang kedua media video animasi berbasis aplikasi Canva untuk posttest. Pretestposttest dilakukan setelah disajikan video. Sebelum pelaksanaan uji coba pretest-postet, video terlebih dahulu diunggah ke kanal Youtube kami. Video ini dibagikan kepada siswa melalui Whatsapp dengan mengirimkan link yang menghubungkan ke youtube. Adapun hasil belajar uji coba pretest-posttest dapat dilihat pada tabel dibawah ini.

Tabel 9

Hasil Belajar Siswa Uji Coba Pretest-Posttest

\begin{tabular}{lllrrrr}
\hline No & Nama & Sekolah & \multicolumn{2}{c}{ Nilai } & Nilai & Kriteria \\
\cline { 3 - 6 } & & Pretest & Posttest & \multicolumn{2}{c}{$\begin{array}{c}\text { Gain } \\
\text { Gain }\end{array}$} & \\
\hline 1 & WIM & SDN 2 Trukan & 95 & 100 & 1 & Tinggi \\
\hline 2 & SC & SDN 2 Trukan & 85 & 95 & 0,67 & Sedang \\
\hline
\end{tabular}


2392 Pengembangan Media Video Animasi Berbasis Aplikasi Canva untuk Meningkatkan Motivasi dan Prestasi Belajar Siswa - Gita Permata Puspita Hapsari, Zulherman

DOI: https://doi.org/10.31004/basicedu.v5i4.1237

\begin{tabular}{|c|c|c|c|c|c|c|}
\hline \multirow[t]{2}{*}{ No } & \multirow[t]{2}{*}{ Nama } & \multirow[t]{2}{*}{ Sekolah } & \multicolumn{2}{|c|}{ Nilai } & \multirow{2}{*}{$\begin{array}{l}\text { Nilai } \\
\text { N- } \\
\text { Gain }\end{array}$} & \multirow[t]{2}{*}{ Kriteria } \\
\hline & & & Pretest & Posttest & & \\
\hline 3 & DS & SDN 2 Trukan & 90 & 95 & 0,5 & Sedang \\
\hline 4 & KWK & SDN 2 Trukan & 100 & 100 & - & - \\
\hline 5 & NVP & SDN 2Trukan & 90 & 100 & 1 & Tinggi \\
\hline 6 & BAH & SDN 2 Trukan & 95 & 95 & 0 & Srabil \\
\hline 7 & HAH & SDN 2 Trukan & 95 & 95 & 0 & Stabil \\
\hline 8 & REC & SDN 2 Trukan & 95 & 95 & 0 & Stabil \\
\hline 9 & AS & SDN 2 Trukan & 80 & 90 & 0,5 & Sedang \\
\hline 10 & $\mathrm{OA}$ & SDN 2 Trukan & 85 & 90 & 0,33 & Sedang \\
\hline 11 & $\mathrm{DP}$ & SDN 3 Watangrejo & 100 & 100 & - & - \\
\hline 12 & $\mathrm{ADA}$ & SDN 3 Watangrejo & 75 & 90 & 0,6 & Sedang \\
\hline 13 & KED & SDN 3 Watangrejo & 85 & 95 & 0,67 & Sedang \\
\hline 14 & SK & SDN 3 Watangrejo & 90 & 95 & 0,5 & Sedang \\
\hline 15 & FP & SDN 3 Watangrejo & 85 & 90 & 0,33 & Sedang \\
\hline 16 & VRK & SDN 3 Watangrejo & 100 & 100 & - & - \\
\hline 17 & $\mathrm{~L}$ & SDN 3 Watangrejo & 80 & 90 & 0,5 & Sedang \\
\hline 18 & VSA & SDN 3 Watangrejo & 95 & 100 & 1 & Tinggi \\
\hline 19 & MDN & SDN 3 Tubokarto & 100 & 100 & - & - \\
\hline 20 & NI & SDN 3 Tubokarto & 100 & 100 & - & \\
\hline 21 & $\mathrm{BBE}$ & SDN 3 Tubokarto & 80 & 100 & 1 & Tinggi \\
\hline 22 & IRA & SDN 3 Tubokarto & 85 & 90 & 0,33 & Sedang \\
\hline 23 & EPM & SDN 3 Tubokarto & 100 & 100 & - & - \\
\hline 24 & AAP & SDN 3 Tubokarto & 95 & 100 & 1 & Tinggi \\
\hline 25 & $\mathrm{D}$ & SDN 3 Tubokarto & 85 & 95 & 0,67 & Sedang \\
\hline 26 & GNN & SDN 3 Tubokarto & 90 & 100 & 1 & Tinggi \\
\hline 27 & AZA & SDN 3 Tubokarto & 85 & 95 & 0,67 & Sedang \\
\hline 28 & KPD & SDN 3 Tubokarto & 95 & 95 & 0 & Stabil \\
\hline 29 & $\mathrm{E}$ & SDN 3 Tubokarto & 60 & 80 & 0,5 & Sedang \\
\hline & & Rata-Rata & & & 0,56 & Sedang \\
\hline
\end{tabular}

Berdasarkan tabel diatas menunjukkan bahwa hasil belajar pada soal pretest sebanyak 28 siswa memperoleh nilai diatas KKM, dimana hanya 1 orang nilainya dibawah KKM. Sedangkan hasil posttest, tidak ada yang mendapat nilai dibawah KKM. Walapun hasil belajar ini termasuk hasil yang bagus karena hampir semua siswa mendapat nilai diatas KKM, bahkan ada beberapa yang mendapatkan nilai sempurna pada hasil pretes-postest, namun hasil belajar siswa banyak yang mengalami peningkatan. Hal ini terbukti dari nilai $\mathrm{N}$ Gain dari hasil pretest-posttest yang telah dilakukan. Berdasarkan nilai N-Gain tersebut diperoleh data sebanyak 6 siswa mengalami peningkatan dengan kategori "Tinggi" dan sebanyak 11 siswa mengalami peningkatan kategori "Sedang". Sedangkan hasil belajar yang masuk kedalam kategori stabil sebanyak 3 siswa dan 6 siswa yang mendapatkan nilai sempurna pada pretest-posttest. Secara keseluruhan rata-rata peningkatan hasil belajar yaitu $0,56 \%$, yang termasuk dalam kategori "Sedang”. Sehingga dapat disimpulkan bahwa media video animasi berbasis aplikasi Canva dapat meningkatkan motivasi dan prestasi belajar siswa. 
2393 Pengembangan Media Video Animasi Berbasis Aplikasi Canva untuk Meningkatkan Motivasi dan Prestasi Belajar Siswa - Gita Permata Puspita Hapsari, Zulherman

DOI: https://doi.org/10.31004/basicedu.v5i4.1237

Penelitian ini serupa dengan penelitian yang dilakukan (Ponza et al., 2018) yang menyatakan bahwa video animasi pembelajaran ini memberikan pengaruh yang signifikan terhadap hasil belajar siswa. Terdapat perbedaan yang signifikan pada hasil belajar Tematik siswa sebelum dan sesudah menggunakan video animasi pembelajaran. Penelitian lain juga menunjukkan bahwa penggunaan media dalam pembelajaran dapat meningkatkan hasil belajar peserta didik atau mencapai sasaran yang diinginkan (Ananda, 2017). Hal ini sejalan dengan pendapat (Rahmatullah et al., 2020) yang menyatakan bahwa media yang akan digunakan merupakan bagian yang terpenting dalam proses desain pembelajaran. Melalui media ini, pesan dari guru ke siswa akan tersampaikan dengan efektif.

Pendapat (Adiputra \& Mujiyati, 2017) mengemukakan bahwa motivasi mendorong siswa untuk dapat melakukan sebuah perilaku, termasuk juga dalam belajar. Siswa bergerak untuk memperolah hasil belajar yang baik jika memiliki motif yang kuat, sehingga motivasi memiliki peran yang penting untuk membuat siswa memperoleh hasil belajar yang baik. Agar motivasi belajar dapat tumbuh dalam diri siswa, maka diperlukan stimulan salah satunya adalah guru yang kreatif. Kreativitas guru dalam pembelajaran dapat diterapkan dalam dua hal yaitu dalam manajemen pembelajaran di kelas dan dalam penggunaan media pembelajaran (Oktiani, 2017).

Penelitian ini memiliki keterbatasan pada saat proses uji coba karena dilaksanakan secara daring melalui Whatsapp sehingga materi yang disampaikan secara konvensional dan media pembelajaran yang digunakan kurang maksimal. Penelitian ini merupakan penelitian terbaru karena dapat digunakan secara luring maupun daring. Hal ini sejalan dengan perkembangan IPTEK yang semakin maju. Hasil perkembangan IPTEK sangat mendukung di dalam proses pembelajaran di sekolah dasar. (Jannah \& Julianto, 2018).

\section{KESIMPULAN}

Berdasarkan hasil analisis dan pembahasan, dapat disimpulkan bahwa media video animasi berbasis aplikasi Canva pada materi gaya dan gerak ini dapat meningkatkan motivasi dan prestasi belajar serta layak digunakan dalam proses pembelajaran.

\section{UCAPAN TERIMA KASIH}

Kami mengucapkan terima kasih kepada pihak-pihak yang telah membantu kami selama proses penelitian.

\section{DAFTAR PUSTAKA}

Adiputra, S., \& Mujiyati, M. (2017). Motivasi dan Prestasi Belajar Siswa di Indonesia: Kajian Meta-Analisis. Konselor, 6(4), 150-157. https://doi.org/10.24036/02017648171-0-00

Ananda, R. (2017). Penggunaan Media Audio Visual untuk Meningkatkan Hasil Belajar Pendidikan Kewarganegaraan Siswa Kelas IV SD Negeri 016 Bangkinang Kota. Jurnal Basicedu, 1(1), 21-30.

Astini, N. K. S. (2020). Pemanfaatan Teknologi Informasi dalam Pembelajaran Tingkat Sekolah Dasar pada Masa Pandemi Covid-19. Jurnal Lembaga Penjaminan Mutu STKIP Agama Hindu Amlapura, 11(2), 1325.

Dadi, I. K., Redhana, I. W., \& Juniartina, P. P. (2019). Analisis Kebutuhan Untuk Pengembangan Media Pembelajaran IPA Berbasis Mind Mapping. Jurnal Pendidikan Dan Pembelajaran Sains Indonesia, 2(2), 70-79.

Dwipayana, P. A. P., Redhana, I. W., \& Juniartina, P. P. (2020). Analisis Kebutuhan Pengembangan Multimedia Interaktif Pembelajaran Ipa SMP. Jurnal Pendidikan Dan Pembelajaran Sains Indonesia, 3(1), 49-60.

Hikmah, V. N., \& Purnamasari, I. (2017). Pengembangan Video Animasi "Bang Dasi" Berbasis Aplikasi Camtasia Pada Materi Bangun Datar Kelas V Sekolah Dasar. Mimbar Sekolah Dasar, 4(2), 182-191. https://doi.org/10.23819/mimbar-sd.v4i2.6352 
2394 Pengembangan Media Video Animasi Berbasis Aplikasi Canva untuk Meningkatkan Motivasi dan Prestasi Belajar Siswa - Gita Permata Puspita Hapsari, Zulherman

DOI: https://doi.org/10.31004/basicedu.v5i4.1237

Jannah, M., \& Julianto, J. (2018). Pengembangan Media Video Animasi Digestive System Untuk Meningkatkan Hasil Belajar Siswa Mata Pelajaran Ipa Kelas V. Jurnal Penelitian Pendidikan Guru Sekolah Dasar, 6(2), 124-134.

Kurniawan, D., Kuswandi, D., \& Husna, A. (2018). Pengembangan Media Video Pembelajaran Pada Mata Pelajaran Ipa Tentang Sifat Dan Perubahan Wujud Benda Kelas Iv Sdn Merjosari 5 Malang. JINOTEP (Jurnal Inovasi Dan Teknologi Pembelajaran) Kajian Dan Riset Dalam Teknologi Pembelajaran, 4(2), 119-125. https://doi.org/10.17977/um031v4i22018p119

Leryan, L. P. A., Damringtyas, C. P., Hutomo, M. P., \& Printina, B. I. (2018). the Use of Canva Application As an Innovative Presentation Media Learning History. Prosiding Seminar Nasional FKIP 2018, 190-203. https://doi.org/10.24071/snfkip.2018.20

Maryanti, S., \& Kurniawan, D. T. (2017). Pengembangan Media Pembelajaran Video Animasi Stop Motion Untuk Pembelajaran Biologi Dengan Aplikasi PICPAC. Jurnal Program Studi Pendidikan Biologi, 8(1), 26-33.

Maulana Arifin, A., Pujiastuti, H., \& Sudiana, R. (2020). Pengembangan media pembelajaran STEM dengan augmented reality untuk meningkatkan kemampuan spasial matematis siswa. Jurnal Riset Pendidikan Matematika, 7(1), 59-73.

http://journal.uny.ac.id/index.php/jrpmhttps://doi.org/10.21831/jrpm.v7i1.32135

Oktaviara, R. A., \& Pahlevi, T. (2019). Pengembangan E-modul Berbantuan Kvisoft Flipbook Maker Berbasis Pendekatan Saintifik pada Materi Menerapkan Pengoperasian Aplikasi Pengolah Kata Kelas X OTKP 3 SMKN 2 Blitar Rhesta Ayu Oktaviara Triesninda Pahlevi. Jurnal Pendidikan Perkantoran, 07(03), 6065 .

Oktiani, I. (2017). Kreativitas Guru dalam Meningkatkan Motivasi Belajar Peserta Didik. Jurnal Kependidikan, 5(2), 216-232. https://doi.org/10.24090/jk.v5i2.1939

Ponza, P. J. R., Jampel, I. N., \& Sudarma, I. K. (2018). Pengembangan Media Video Animasi pada Pembelajaran Siswa Kelas IV di Sekolah Dasar. Jurnal Edutech Undiksha, 6(1), 9-19.

Putri, A. S. (2020). Pengaruh Perkembangan Ilmu dan Teknologi Terhadap Perubahan Ruang. Kompas.Com. https://www.kompas.com/skola/read/2020/06/24/163000969/pengaruh-perkembangan-ilmu-danteknologi-terhadap-perubahan-ruang?page=all

Rahmatullah, R., Inanna, I., \& Ampa, A. T. (2020). Media Pembelajaran Audio Visual Berbasis Aplikasi Canva. Jurnal Pendidikan Ekonomi Undiksha, 12(2), 317-327.

Silmi, M. Q., \& Rachmadyanti, P. (2018). Pengembangan Media Pembelajaran Video Animasi Berbasis Sparkol Videoscribe Tentang Persiapan Kemerdekaan Ri Sd Kelas V. Jurnal Penelitian Pendidikan Guru Sekolah Dasar, 6(4), 486-495.

Tafonao, T. (2018). Peranan Media Pembelajaran Dalam Meningkatkan Minat Belajar Mahasiswa. Jurnal Komunikasi Pendidikan, 2(2), 103-114. https://doi.org/10.32585/jkp.v2i2.113

Tanjung, R. E., \& Faiza, D. (2019). Canva Sebagai Media Pembelajaran Pada Mata Pelajaran Dasar Listrik Dan Elektronika Rahma Elvira Tanjung 1), Delsina Faiza 2) 1. Jurnal Vokasional Teknik Elektronika Dan Informatika, 7(2), 79-85.

WHO. (2021). WHO Coronavirus Disease (COVID-19) Dashboard. World Health Organization. https://covid19.who.int/

Zulherman, Amirullah, G., Purnomo, A., \& Aji, G. B. (2021). Development of Android-Based Millealab Virtual Reality Media in Natural Science Learning. Jurnal Pendidikan Sains Indonesia (Indonesian Journal of Science Education), 9(1), 1-10. https://doi.org/10.24815/jpsi.v9i1.18218 